\title{
The relationship between anthropometry and ankle-brachial index with blood glucose level in patients with type 2 diabetes mellitus at the Community Health Center in Medan, Indonesia
}

\author{
RINA AMELIA 1, A-G, BURHAN BURHAN ${ }^{2, B-E}$, AZNAN LELO 3, A, D-F \\ ORCID ID: 0000-0002-0419-9622 \\ ${ }^{1}$ Faculty of Medicine, Universitas Sumatera Utara, Medan, Indonesia \\ ${ }^{2}$ Medical student, Faculty of Medicine Universitas Sumatera Utara, Medan, Indonesia \\ ${ }^{3}$ Department of Pharmacology and Therapeutics, Faculty of Medicine Universitas Sumatera Utara, Medan, Indonesia
}

A - Study Design, B - Data Collection, C - Statistical Analysis, D - Data Interpretation, E - Manuscript Preparation, F - Literature Search, G - Funds Collection

Summary Background. Diabetes mellitus (DM) is a group of metabolic diseases with characteristics of hyperglycemia due to abnormalities of insulin secretion, impaired insulin function or both. Increased blood sugar levels in the body can cause the changes within the body, which then can be measured by using anthropometry as well as the measurement of vascularization changes to the periphery. Objectives. This study aimed to determine the relationship between anthropometry and ankle-brachial index (ABI) with blood glucose level (BGL) in patients with type 2 diabetes mellitus at Tuntungan Community Health Center in Medan.

Material and methods. The study design was a cohort observational cross-sectional study. Research samples were patients with type 2 diabetes mellitus in Tuntungan Community Health Center determined by consecutive sampling; inclusion and exclusion criteria were also considered. Primary data was used as the data source for the study. Anthropometry and ankle-brachial index were directly measured from diabetic patients whereas ad random BGL was measured using a portable device. Data were analyzed using SPSS computer program. Results. Among 101 diabetic respondents, the results showed that 65 respondents (64.3\%) had normal ad random blood glucose level while 36 respondents (35.6\%) were hyperglycemic. Based on the results of chi-square, there was a relationship found between $\mathrm{BMI}$, $\mathrm{ABI}$, waist circumference, and $\mathrm{BGL}(p=0.001 ; p=0.0001 ; p=0.0001)$. In contrast, no relationship was found between blood pressure, waist-hip ratio, upper arm circumference, and $\mathrm{BGL}(p=0.07 ; p=0.37 ; p=0.77)$.

Conclusions. The results showed that uncontrolled BGL very closely related to complications experienced by patients such as macro vascular complications.

Key words: anthropometry, ankle-brachial index, blood glucose level, type 2 diabetes mellitus.

Amelia R, Burhan B, Lelo A. The relationship between anthropometry and ankle-brachial index with blood glucose level in patients with type 2 diabetes mellitus at the Community Health Center in Medan, Indonesia. Fam Med Prim Care Rev 2018; 20(4): 307-312, doi: https://doi.org/10.5114/fmpcr.2018.79339.

\section{Background}

Diabetes mellitus is a group of metabolic disease characterized by hyperglycemia, which is caused by insulin secretion abnormalities, impaired functions of insulin, or both [1]. The classical symptoms of diabetes were polyuria, polyphagia, and polydipsia. Epidemiologically, it is predicted that Diabetes Mellitus in Indonesia will amount to approximately 21.3 million cases in 2030 , and about $80 \%$ of these cases will be Type 2 Diabetes Mellitus. The prevalence of diabetic patients in Indonesia is the seventh highest, with 10 million cases, after China, India, and the United States. According to the Indonesian Basic Health Research in 2013, the prevalence of diabetes mellitus in Indonesia was $6.9 \%$ [2].

Obesity is one of the risks of diabetes, as obesity will lead to decreased sensitivity of hepatic and peripheral insulin, and the secondary phenomenon is a moderate increase of insulin secretion to overcome insulin resistance. Furthermore, central obesity increases this case. The indicator of obesity can be determined with the measurement of anthropometries, such as Body Mass Index (BMI), including body weight and height, waist circumference, and waist-hip ratio; these three aspects can measure central obesity. Anthropometric measurement is also a routine examination to determine the risk of metabolic diseases, one of which is diabetes mellitus [3]. Anthropometry is often used as a health indicator under normal conditions, as well as with athletes and diabetic patients [4-6]. Anthropometric measurements can be a controlled parameter for diabetes. A normal anthropometric value would explain that the patient has a good diet, exercise and take medication so that the patient would avoid complications. Several studies have suggested an association between anthropometry with BGL and a reduced risk of cardiovascular complications in diabetic patients $[5,6]$.

Higher BGL in diabetic patients is one of the risk factors for the occurrence of macro vascular disorders. According to the International Diabetes Federation, there are triad diseases of macro vascular disorders in people with diabetes mellitus: coronary heart disease, cerebrovascular disease, and peripheral vascular disease (PVD), including peripheral arterial disease (PAD) [7]. Based on the results of previous studies showing an increased incidence of PAD in diabetic patients, it is estimated that the prevalence of PAD in white males is 10.97 (OR: 2.15), and the prevalence in white females is 12.89 (OR: 2.73) [8]. Peripheral Arterial Disease is a risk for amputation of the inferior extremities, especially in patients with diabetes mellitus, and sufferers are at $2-5$ times greater risk for cardiovascular disease and cerebrovascular events that are fatal and end in death. The quality of life of patients with DM and PAD will be disrupted due 
to functional limitations and increasingly severe symptoms, and thus the productivity of working patients decreases [9]. Early detection of PAD is very important, especially in patients with diabetes, as early detection can limit the risk of myocardial infarct (MI) or stroke and reduce the morbidity and mortality rate of cardio-cerebrovascular disease and avoid the risks that can occur in patients with diabetes, such us ulcer, gangrene, amputation of inferior extremity due to ischemia, which will have an impact on functional limitations [10-12]. Early management of PAD in patients showed significant improvement in the quality of life $[9,13]$. The Peripheral Arterial Disease diagnostic approach can be done through anamnesis, physical examination of palpation pulse arteria dorsalis pedis and arteria Tibialis posterior, as well as the measurement of ankle-brachial index (ABI) [11].

Peripheral Arterial Disease is a condition characterized by narrowing of the peripheral artery due to atherosclerosis, and it generally occurs in the arteries of the legs. The American College of Cardiology Foundation (ACCF) and the American Heart Association (AHA) recommend performing an ankle-brachial index $(A B I)$ examination in patients with PAD risk factors, such as diabetes mellitus [9]. This procedure has a high sensitivity (79$-95 \%$ ) and specifications (95-96\%) compared to angiography as a standard to determine the extent to which PAD events have occurred in patients at risk, including diabetes mellitus. The examination of the ankle-brachial index is a gold standard for non-invasive measurement of PAD detection and is recommended as part of an assessment of individuals at risk for the disease. The measurement of $A B I$ is the first line of non-invasive screening and diagnosis of PAD [9].

\section{Objectives}

The purpose of this study was to analyze the relationship between anthropometry and ankle-brachial index with blood glucose level in patients with type 2 diabetes mellitus at the Tuntungan Community Health Center.

\section{Material and methods}

\section{Study design} study.

The study design was a cohort observational cross-sectiona

\section{Study location and respondents}

The population of this study was all patients with type 2 diabetes. The reason for choosing Tuntungan Community Health Center as the study location was because it is one of the community health centers in Medan City which has wide area coverage and a dense population, as well as it is a place of study and was built by University of Sumatera Utara. Based on the data, the number of diabetes patients increases every month. The inclusion criteria were patients with type 2 diabetes in the working area of the Tuntungan Community Health Center aged 35-65 years, patients who have suffered from diabetes for at least one year, patients who visited the health center independently, and patients who were willing to participate in the research. On the other hand, the exclusion criteria were patients having experienced marked PAD by amputation of one of the extremities, patients experiencing terminal illness, diabetic patients with complications who could not visit the health center independently, and pregnant diabetic patients. The number of samples in this study was 101 patients, determined by a single sample formula for the hypothesis of the population proportion, while the samples were recruited utilizing the consecutive sampling method.

Before the research, this research protocol has been approved by the research ethics committee at the Faculty of Medicine Universitas Sumatera Utara, and all participants who are willing to participate in the research have signed written informed consent.

\section{Measurements}

The source of research data is primary data. Assessment of nutritional status was based on Body Mass Index (BMI), e.g. body weight and height measured at the time of research, waist or hip circumference determined with a tape measure, and ABI, determined with measurement of the highest systolic blood pressure from two extremities in the ankle and brachial areas. The data from the BGL was random glucose and from capillary blood. Measurement of BGL was performed just once (after anthropometric and $\mathrm{ABI}$ measurements). Blood glucose level was measured using a glucose-stick, and the capillary blood of the patient was taken and then read using a glucose-meter. The result of the blood glucose measurement is expressed in $\mathrm{mg} /$ $/ d \mathrm{~L}$. The reason of using capillary glucose level were that it was more easy, more simple, more convenient and more acceptable then venous glucose level, so it would be effective in monitoring and controlling the diabetes. Based on socio-economic factors, it is known that only a few patients have their own glucose-meter, thus a blood sugar examination is one reason for patients to come for treatment at the community health center. All patients participating in the study completed an informed consent form. Data was analyzed using the chi-square test with the SPSS computer program. The confidence interval was set at $95 \%$, and a $p$-value of $<0.05$ was considered significant.

\section{Results}

The number of patients who fulfilled the inclusion and exclusion criteria in this study was 101 patients in the Tuntungan Community Health Center, and the characteristics of the patients can be seen in Table 1 .

Table 1. Basic characteristics of diabetes patients in the Tuntungan Community Health Center

\begin{tabular}{|c|c|c|}
\hline & $\begin{array}{l}\text { Frequency } \\
(n)\end{array}$ & $\begin{array}{l}\text { Percentage } \\
(\%)\end{array}$ \\
\hline \multicolumn{3}{|l|}{ Gender } \\
\hline $\begin{array}{l}\text { Male } \\
\text { Female }\end{array}$ & $\begin{array}{l}57 \\
44 \\
\end{array}$ & \begin{tabular}{|l|}
56.4 \\
43.6 \\
\end{tabular} \\
\hline \multicolumn{3}{|l|}{ Age group } \\
\hline $\begin{array}{l}\text { Early adolescent ( } 26-35 \text { years old) } \\
\text { Late adolescent ( } 36-45 \text { years old) } \\
\text { Early elderly ( } 46-55 \text { years old) } \\
\text { Middle elderly ( } 56-65 \text { years old) }\end{array}$ & $\begin{array}{l}1 \\
25 \\
52 \\
23\end{array}$ & $\begin{array}{l}0.9 \\
24.8 \\
51.5 \\
22.8\end{array}$ \\
\hline \multicolumn{3}{|l|}{ Duration of illness } \\
\hline $\begin{array}{l}1-5 \text { years } \\
6-10 \text { years } \\
11-15 \text { years } \\
>15 \text { years }\end{array}$ & $\begin{array}{l}22 \\
65 \\
12 \\
2 \\
\end{array}$ & $\begin{array}{l}21.8 \\
64.4 \\
11.9 \\
1.9 \\
\end{array}$ \\
\hline \multicolumn{3}{|l|}{ Family history } \\
\hline $\begin{array}{l}\text { Present (maternal) } \\
\text { Present (paternal) } \\
\text { Not present }\end{array}$ & $\begin{array}{l}50 \\
39 \\
12 \\
\end{array}$ & $\begin{array}{l}49.5 \\
38.6 \\
11.9 \\
\end{array}$ \\
\hline \multicolumn{3}{|l|}{ Complaints often felt } \\
\hline $\begin{array}{l}\text { Numb foot } \\
\text { Weakness } \\
\text { Polyphagia } \\
\text { Polydipsia } \\
\text { Polyuria }\end{array}$ & $\begin{array}{l}44 \\
11 \\
40 \\
2 \\
4\end{array}$ & $\begin{array}{l}43.6 \\
10.9 \\
39.7 \\
1.9 \\
3.9 \\
\end{array}$ \\
\hline \multicolumn{3}{|l|}{ Use of anti-diabetic drugs } \\
\hline $\begin{array}{l}\text { Glibenclamide } \\
\text { Metformin }\end{array}$ & $\begin{array}{l}33 \\
68 \\
\end{array}$ & $\begin{array}{l}32.7 \\
67.3\end{array}$ \\
\hline \multicolumn{3}{|l|}{ Use of insulin } \\
\hline $\begin{array}{l}\text { Present } \\
\text { Not present }\end{array}$ & $\begin{array}{l}54 \\
47 \\
\end{array}$ & $\begin{array}{l}53.5 \\
46.5 \\
\end{array}$ \\
\hline
\end{tabular}




\begin{tabular}{|c|c|c|}
\hline & $\begin{array}{l}\text { Frequency } \\
(n)\end{array}$ & $\begin{array}{l}\text { Percentage } \\
(\%)\end{array}$ \\
\hline \multicolumn{3}{|c|}{ Acanthosis nigricans } \\
\hline $\begin{array}{l}\text { Present } \\
\text { Not present }\end{array}$ & $\begin{array}{l}37 \\
64\end{array}$ & $\begin{array}{l}36.6 \\
63.4\end{array}$ \\
\hline \multicolumn{3}{|l|}{ Ethnic groups } \\
\hline $\begin{array}{l}\text { Batak } \\
\text { Karo } \\
\text { Melayu } \\
\text { Padang } \\
\text { Jawa }\end{array}$ & $\begin{array}{l}35 \\
28 \\
15 \\
13 \\
10\end{array}$ & \begin{tabular}{|l|}
34.7 \\
27.7 \\
14.8 \\
12.9 \\
9.9
\end{tabular} \\
\hline \multicolumn{3}{|l|}{ Exercise } \\
\hline $\begin{array}{l}\text { Present } \\
\text { Not present }\end{array}$ & $\begin{array}{l}4 \\
97\end{array}$ & \begin{tabular}{|l|}
4.0 \\
96.0
\end{tabular} \\
\hline \multicolumn{3}{|l|}{ Blood pressure } \\
\hline $\begin{array}{l}\text { Hypertension } \\
\text { No hypertension }\end{array}$ & $\begin{array}{l}87 \\
14\end{array}$ & $\begin{array}{l}86.1 \\
13.9\end{array}$ \\
\hline \multicolumn{3}{|l|}{ BMI } \\
\hline $\begin{array}{l}\text { Normal weight } \\
\text { Obese }\end{array}$ & $\begin{array}{l}16 \\
85\end{array}$ & $\begin{array}{l}15.8 \\
84.2\end{array}$ \\
\hline Total & 101 & 100 \\
\hline
\end{tabular}

Based on Table 1, the number of male patients was higher than females with 57 people (56.4\%). According to the age group, it is known that most of the respondents were classified as the early elderly group (46-55 years) with 52 people (51.5\%), and about 65 patients (64.4\%) have suffered from diabetes for 6-10 years. The number of patients who had a family history of diabetes mellitus, either from the father or mother, was 89 people $(88.1 \%)$, while the complaints are often felt by patients was numb legs with 44 people $(43.6 \%)$, followed by frequent hunger with 40 people (39.6\%); 54 patients (53.5\%) used insulin, whereas 47 patients (46.5\%) did not use insulin; 33 patients $(32.7 \%)$ consumed glibenclamide, while 68 patients $(67.3 \%)$ consumed metformin. Among 101 diabetic patients, 37 people $(36.6 \%)$ had acanthosis nigricans, the majority from the ethnic Batak people ( $35 ; 34.7 \%)$; and 97 patients $(96 \%)$ did not perform regular exercise. About 87 patients $(86.1 \%)$ also suffered from hypertension, and 85 patients ( $84.2 \%$ ) were found to be obese.

According to Table 2, 62 patients (61.4\%) had a waist circumference at risk, and 32 patients (31.6\%) were classified into the hyperglycemic group. 62 patients $(61.4 \%)$ had an at-risk waisthip ratio, but only 20 of them (19.8\%) were classified into the hyperglycemic group. Based on the examination of upper arm circumference, it was found that 27 patients $(26.7 \%)$ were found to be obese, as the value of upper arm circumference was above $32 \mathrm{~cm} ; 9$ (8.9\%) of them were classified into the hyperglycemic group. The number of diabetic patients with obesity classified into the hyperglycemic group was 36 patients (35.6\%), and 87 patients $(86.1 \%)$ also suffered from hypertension, in which 28 of them $(27.7 \%)$ were classified into the hyperglycemic group. The number of diabetic patients with a decreased $A B I$ value classified into the hyperglycemic group was 2 patients (1.9\%).

The chi-square test results showed that there was a relationship between waist circumference, $\mathrm{BMI}$, and $\mathrm{ABI}$ with $\mathrm{BGL}$ $(p=0.0001 ; p=0.001 ; p=0.0001)$, whereas no relationship was found between waist-hip ratio, upper arm circumference, and blood pressure with BGL ( $p=0.37 ; p=0.481 ; p=0.07)$.

\section{Discussion}

Based on the demographic characteristics of the patients, 89 patients had a family history of diabetes. Previous studies have suggested that a person who has a family history of diabetes was significantly and independently associated with diabetes, and they are 2-6 times more at risk of developing diabetes. Furthermore, people with a family history of diabetes are at risk of having higher BMI (overweight, obese) and highest average blood glucose [14-17]. This is because individuals with a genetic predisposition to diabetes show a lower beta-cell compensation response to decreased insulin sensitivity associated with obesity $[15,17]$. These findings help explain the multiplication effect

\begin{tabular}{|c|c|c|c|c|}
\hline & \multicolumn{2}{|c|}{ Blood glucose level } & \multirow[t]{2}{*}{ Total (\%) } & \multirow[t]{2}{*}{$p$} \\
\hline & Normal (\%) & Hyperglycemia (\%) & & \\
\hline \multicolumn{5}{|l|}{ Waist circumference } \\
\hline Risk ( $\left.+:>80 \mathrm{~cm} ; \partial^{\lambda}:>90 \mathrm{~cm}\right)$ & $30(29.7)$ & $32(31.6)$ & $62(61.4)$ & \multirow[t]{2}{*}{0.0001} \\
\hline Not at risk $\left(q: \leq 80 \mathrm{~cm} ;{ }^{\lambda}: \leq 90 \mathrm{~cm}\right)$ & $35(34.6)$ & $4(4)$ & $39(38.6)$ & \\
\hline \multicolumn{5}{|l|}{ Waist-hip ratio } \\
\hline Risk (q: $\left.\geq 0.80 ; \partial^{\lambda}: \geq 0.95\right)$ & $42(41.5)$ & $20(19.8)$ & $62(61.4)$ & \multirow[t]{2}{*}{0.37} \\
\hline Not at risk $(+9:<0.80 ; \widehat{O}:<0.95)$ & $23(22.7)$ & $16(15.8)$ & $39(38.6)$ & \\
\hline \multicolumn{5}{|l|}{ Upper arm circumference } \\
\hline Obese (> $32 \mathrm{~cm})$ & $18(17.8)$ & $9(8.9)$ & $27(26.7)$ & \multirow[t]{2}{*}{0.481} \\
\hline Good nutrition $(<32 \mathrm{~cm})$ & $47(46.5)$ & $27(26.7)$ & $74(73.3)$ & \\
\hline \multicolumn{5}{|l|}{ BMI } \\
\hline Obese ( $\geq 23)$ & $49(48.5)$ & $36(35.6)$ & $85(84.1)$ & \multirow[t]{2}{*}{0.001} \\
\hline Normal weight (18.5-22.9) & $16(15.9)$ & $0(0)$ & $16(15.9)$ & \\
\hline \multicolumn{5}{|l|}{ Blood pressure } \\
\hline Hypertension ( $\geq 130 / 90)$ & $59(58.4)$ & $28(27.7)$ & $87(86.1)$ & \multirow[t]{2}{*}{0.07} \\
\hline Normal (<130/90) & $6(5.9)$ & $8(7.9)$ & $14(13.9)$ & \\
\hline \multicolumn{5}{|l|}{$A B I$} \\
\hline Decrease $(<0.90)$ & $26(25.7)$ & $2(1.9)$ & $28(27.7)$ & \multirow[t]{2}{*}{0.0001} \\
\hline Normal (0.91-1.30) & $39(38.6)$ & $34(33.6)$ & $73(72.3)$ & \\
\hline Total & 65 (64.3) & 36 (35.6) & $101(100)$ & \\
\hline
\end{tabular}


of family history and obesity on the risk of type 2 diabetes [16]. Between the father and mother, they presented equivalent risk ratios for type 2 diabetes [12, 17].

About 37 diabetic patients (36.6\%) had acanthosis nigricans. The incidence rate for acanthosis nigricans is not exactly known. However, it is found that obesity is closely associated with acanthosis nigricans, and more than half of the adults with body weight over $200 \%$ of the ideal body weight had acanthosis nigricans [18]. Acanthosis nigricans is said to be associated with race and is commonly found in people with dark skin. The prevalence in Caucasians is less than $1 \%$, while the prevalence in Latinos is $5.5 \%$, and in Africans, it is $13.3 \%$. In this study, the incidence of acanthosis nigricans was most likely influenced by nutritional status and not by ethnicity/race, as all of the diabetic patients' ethnicity/race, is generally in the same scope (Mongoloid).

The results showed that $61.4 \%$ of the patients had a waist circumference in the category of risk. The factor of age and less physical activity in diabetic patients causes changes in the proportion of fat and muscle in the body. The older a person, the more body fat, less muscles and less physical activity cause the muscle mass decreased, so that the use of blood sugar is reduced, and the resulting blood sugar tends to increase in this group [19-21]. The chi-square test showed that there was a relationship between waist circumference and BGL. The relationship between waist circumference and BGL had a positive pattern trend, which means that the larger the waist circumference, the higher the blood sugar level. An excessive increase in visceral fat can decrease adiponectin production. Decreased adiponectin may increase the risk of metabolic disorders, such as insulin resistance, which can affect hyperglycemia [6, 20-24].

In this study, it was found that there was no significant relationship between waist-hip ratio and BGL $(p=0.370)$. Waist-hip ratio is often used as a measure of central/abdominal obesity, and central obesity suggests a change in the homeostasis of glucose-insulin in the body, which can lead to accumulation of fatty tissue. The results of this study were not in line with previous research, which found that there was a relationship between waist-hip ratio and BGL $[6,25]$. These differences may be due to differences in the age groups, as age differences might determine body composition, which affects the distribution of muscle mass and total body fat $[23,26]$. A majority of the patients in this study were within the age of 46-55 years, while previous studies recruited younger patients.

There was no relationship between upper arm circumference and BGL in diabetic patients in the Tuntungan Community Health Center (chi-square test with $p$-value $=0.481$ ). Previous studies showed that there was a positive correlation between upper arm circumference and BGL in diabetic patients [19-22]. This might be due to differences in the selection of cut-off points in this study, making the result different from previous studies [23, 26].

A significant association between BMI and average BGL was found $(p=0.001)$. Body Mass Index is an indicator for evaluating obesity and overweight in adults. About $70 \%$ of diabetic patients are overweight, and more than $50 \%$ of obese patients undergo a decrease in glucose tolerance, which causes hyperglycemia and may affect $\mathrm{BMI}[6,20-25]$. BMI as a measure to determine obesity has some limitations. Firstly, BMI cannot distinguish between fat mass and lean body mass. Another weakness is that BMI highly depends on age, gender, and ethnicity. One of the risk factors for type 2 diabetes is central obesity, where visceral/ /abdominal fat is more unstable and has higher access to circulation; thus, it is more likely to cause morbidity and decrease the quality of life. Body Mass Index has a strong relationship with diabetes and insulin resistance. In obese individuals, the amount of non-esterified fatty acids, glycerol, hormones, cytokines, proinflammatory markers, and other substances that are involved in the development of insulin resistance is increased. The pathogenesis in the development of diabetes is based on the fact that the $\beta$-islet cells of the pancreas are impaired, caus- ing a lack of control of blood glucose. The development of diabetes becomes more inevitable if the failure of $\beta$-islet cells of the pancreas is accompanied by insulin resistance. Weight gain and body mass are central to the formation and rising incidence of type 1 and type 2 diabetes [27].

The study showed no significant relationship between blood pressure and average BGL $(p>0.05)$. This result is different from literature that states that hypertension is a comorbid condition, which is commonly found in both type 1 or 2 diabetes. The American Diabetes Association reported that $71 \%$ of diabetic patients had a blood pressure of $140 / 90 \mathrm{~mm} \mathrm{Hg}$ or more from 2000 to 2012 [22, 28]. When an individual has both hypertension and diabetes, the side effect of either one disease can worsen the condition of the other disease. This is because both hypertension and diabetes have the same risk factors, including overweight and less active lifestyle [5, 26, 31, 32]. A study conducted in Morocco showed that $70.4 \%$ of patients with type 2 diabetes had hypertension as well. This study might explain the different frequency of each country, which is caused by different surveillance methods, a difference definition of hypertension, population characteristics, and ethnic variations [28, 33, 34]. No relationship was found between blood pressure and average BGL in this study, which might be due to other factors, such as age. It is known that age becomes a risk factor for the increase in blood pressure [35].

Based on this study, we found that there was a significant relationship between $A B I$ and $B G L(p=0.0001)$, which means that there was a significant decrease in the value of $A B I$ in people with diabetes mellitus. This condition occurs due to endothelial dysfunction and the condition of atherosclerosis due to hyperglycemia, resulting in narrowing of the lumen of the blood vessels up to the periphery $[11,29]$. Lumen reduction leads to decreased peripheral circulation; this circulation deficit causes a decrease in the ankle-brachial index (ABI) value [30, 31, 36-38]. This condition is characterized by frequent complaints of numbness in the extremities, as in most of the complaints experienced by 44 patients ( $43.6 \%)$.

\section{Limitations of the study}

Firstly, this study was a cross-sectional study; therefore, this study was not able to check the history of the disease and the problems experienced by the patients from the beginning of diabetes, including the nutritional status of the patients. Furthermore, this research did not differ diabetes patients with a risk of vascular disorders, such as smoking, hyper-cholesterol, and other diseases which can clog the leg veins; thus, the results were less specific. Secondly, an examination of patients with diabetes is the only available examination at primary level service, such us random BGL, anthropometry, and blood pressure, and thus $\mathrm{HbA}_{1}$ examination, which is one of the specific and objective specific control parameters for diabetic patients, is not performed, as this was not available here. In the future study, we plan to measure the $\mathrm{HbA}_{1 \mathrm{c}}$ level and lipid profile of type 2 diabetes patients at the Tuntungan Community Health Center. Thirdly, this study was conducted in only one working area of the community health center in Medan city, so that the number of patients was only limited to patients with type 2 diabetes who came to the community health center. Even there were not specific inclusion and exclusion criteria instead of general health condition of the diabetes patients, this study provide important issue about the condition of diabetes patients that need to be studied in the future with better study design.

\section{Conclusions and recommendations}

From the results of the study, it can be seen that there is a relationship between dietary regulation with BGL control, where uncontrolled BGL was very closely related to complications experienced by patients, such as macro vascular complications. 
It is recommended to family doctors working in primary care: Firstly, to improve education and enhance the understanding and independence of diabetes patients, and thus the patients will be able to manage the disease independently. Secondly, to carry out periodic $A B I$ examinations to prevent and make early diagnosis of PAD in people with type 2 diabetes mellitus, as early efforts can improve the prognosis and progression of the disease, as well as prevent further complications that can decrease the quality of life of the patient.

Source of funding: This work was funded by Research Institute Universitas Sumatera Utara in accordance with Research Contract TALENTA Universitas Sumatera Utara fiscal year 2017 No. 5338/UN5.1.R/PPM/2017 Date May 22, 2017.

Conflicts of interest: The authors declare no conflicts of interest.

\section{References}

1. Perkumpulan Endokrinologi Indonesia (PERKENI). Konsensus Pengendalian dan Pencegahan Diabetis Mellitus Tipe2 di Indonesia. Jakarta: PB Perkeni; 2015 (in Indonesian)

2. Bilous RW, Pangemanan C, Rakyat AL. Seri Kesehatan Bimbingan Dokter pada Diabetes. Jakarta: Dian Rakyat; 2002 (in Indonesian).

3. Selvin E, Marinopoulus S, Berkenbilt G, et al. Meta-analysis glycosylated hemoglobin and cardiovascular disease in diabetes mellitus. Ann Intern Med 2004; 141: 421-431.

4. Jelavic M, Babic Z, Pintaric H. The importance of two metabolic syndrome diagnostic criteria and body fat distribution in predicting clinical severity and prognosis of acute myocardial infarction. Arch Med Sci 2016; 13(4): 795-806.

5. Milić M, Grgantov Z, Chamari K, et al. Anthropometric and physical characteristics allow differentiation of young female volleyball players according to playing position and level of expertise. Biol Sport 2016; 34(1): 19-26.

6. Amelia R. The correlation between Body Mass Index and self-efficacy with blood glucose level in Type 2 Diabetes Mellitus. Adv Sci Lett 2017; 23(4): 3606-3609.

7. International Diabetes Federation (IDF). Atlas ID. 8th ed. Brussels: International Diabetes Federation; 2017.

8. Eraso LH, Fukaya E, Mohler III ER, et al. Peripheral arterial disease, prevalence and cumulative risk factor profile analysis. Eur J Prev Cardiol 2014; 21(6): 704-711.

9. Eason SL, Petersen NJ, Suarez-Almazor M, et al. Diabetes mellitus, smoking, and the risk for asymptomatic peripheral arterial disease: whom should we screen? JBFP 2005; 18(5): 355-361.

10. Hirsch AT, Criqui MH, Treat-Jacobson D, et al. Peripheral arterial disease detection, awareness, and treatment in primary care. JAMA 2001; 286(11): 1317-1324.

11. American Diabetes Association. Diagnosis and Classification of Diabetes Mellitus. Diabetes Care 2014; 34(1): 62-69.

12. Amelia R, Damanik HA, Lindarto D, et al. The correlation between the level of $\mathrm{HbA}_{1 c}$ with total serum cholesterol of uncontrolled Type 2 Diabetes Mellitus patients in Binjai, Sumatera Utara. Adv Sci Lett 2017; 23(4): 3610-3613.

13. Amelia R, Lelo A, Lindarto $D$, et al. Quality of life and glycemic profile of type 2 diabetes mellitus patients of Indonesian: a descriptive study. IOP Conf Ser: Earth Environ Sci 2018; 125(1): 012171, doi: 10.1088/1755-1315/125/1/012171.

14. Roger VL, Go AS, Lloyd-Jones DM, et al. Heart disease and stroke statistics - 2011 update: a report from the American Heart Association. Circulation 2011; 123(4): e18-e209, doi: 10.1161/CIR.0b013e3182009701.

15. Harrison TA, Hindorff LA, Kim H, et al. Family history of diabetes as a potential public health tool. Am J Prev Med 2003; 24(2): 152-159.

16. Meigs JB, Cupples LA, Wilson PW. Parental transmission of type 2 diabetes: the Framingham Offspring Study. Diabetes 2000; 49(12): 2201-2207.

17. Elbein SC, Wegner K, Kahn SE. Reduced beta-cell compensation to the insulin resistance associated with obesity in members of caucasian familial type 2 diabetic kindreds. Diabetes Care 2000; 23(2): 221-227.

18. Sande van der MA, Walraven GE, Milligan PJ, et al. Family history: an oppurtunity for early interventions and improved control of hypertension, obesity, and diabetes. Bull World Health Organ 2001; 79(4): 321-328.

19. Acanthosis Nigricans: Background, Pathophysiology, Etiology [editorial]. Available from URL: Emedicine.medscape.com.

20. Mayasari N. Hubungan Lingkar Leher dan Lingkar Pinggang dengan Kadar Gula Darah Puasa Orang Dewasa [skripsi]. Semarang: Fakultas Kedokteran Universitas Diponegoro; 2014 (in Indonesian).

21. Pusparini P. Obesitas Sentral, sindrom metabolik, dan diabetes mellitus tipe 2. Universa Medicina 2007; 26(4): 195-204 (in Indonesian).

22. Etukumana EA, Puepet FH, Obadofin MO. Relationship of Blood Glucose Levels with Waist Circumference, Hip Circumference, and Waist Hip Ratio among rural adults in Nigeria. Asian J Pharm Clin Res 2014; 7(91): 204-206.

23. Kharal PM, Prasad PN, Acharya RP. Gross correlation between Waist Hip Ratio and Blood Sugar Level in a village. J Nepal Med Assoc 2013; 52(190): 361-364.

24. Reinders I, Visser M, Schaap L. Body weight and body composition in old age and their relationship with frailty. Ageing: biology and nutrition. Curr Opin Clin Nutr Metab Care 2017; 20(1): 11-15.

25. Devang N, Nandini M, Rao S, et al. Mid arm cicumference: an Alternate Anthropometric Index of Obesity in Type 2 Diabetes and metabolic syndrome. BrJ Med Med Res 2016; 12(1): 1-8.

26. Hadi DDR. Hubungan antara Indeks Massa Tubuh (IMT) dan Lingkar Lengan Atas (LiLA) dengan Kadar gula darah dan kolesterol pada wanita subur (WUS) di Kecamatan Cangkringan Kabupaten Sleman. Surakarta: Fakultas Ilmu Kesehatan Universitas Muhammadiyah Surakarta; 2013 (in Indonesian).

27. Al-Goblan AS, Al-Alfi MA, Khan MZ. Mechanism linking diabetes mellitus and obesity. Diabetes Metab Syndr Obes 2014; 7: 587-591.

28. Hartono A. Terapi Gizi dan Diet Rumah Sakit. Jakarta: EGC; 2006 (in Indonesian).

29. Agrawal N, Agrawal MK, Kumari T, et al. Correlation between body mass index and blood glucose levels in Jharkhand population. IJCMR 2017; 4(8): 1633-1636.

30. Innocent $\mathrm{O}$, ThankGod OO, Sandra EO, et al. Correlation between body mass index and blood glucose levels among some Nigerian undergraduates. HOAJ Biology 2013; 2(4), doi: http://dx.doi.org/10.7243/2050-0874-2-4.

31. Arif M, Ernalia Y, Rosdiana D. Hubungan Indeks Massa Tubuh dengan Kadar Gula Darah Puasa pada Pegawai Sekretariat Daerah Provinsi Riau. JOM 2014; 1(2). Available from URL: https://media.neliti.com/media/publications/188627-ID-hubungan-indeks-massa-tubuhdengan-kadar.pdf (in Indonesian).

32. Esptein M, Sowers JR. Diabetes mellitus and hypertension. Hypertension 1992; 19(5): 403-418.

33. Berraho M, El Achhab Y, Benslimane A, et al. Hypertension and type 2 diabetes: a cross- sectional study in Morocco (EPIDIAM Study): Pan Afr Med J 2012: 11(52): PMC3343680. 
34. Mutmainah I. Hubungan Kadar Gula Darah Dengan Hipertensi Pada Pasien Diabetes Melitus Tipe 2 Di Rumah Sakit Umum Daerah Karanganyar (Doctoral dissertation). Universitas Muhammadiyah Surakarta (in Indonesian).

35. Amelia R, Harahap J, Wahyuni AS, et al. Health status of elderly based on daily activities living, cholesterol and uric acid profile in Medan city. IOP Conf Ser: Earth Environ 2018; 125(1): 012175, doi: 10.1088/1755-1315/125/1/012175.

36. Creager MA, Lüscher TF, Cosentino F, et al. Diabetes and vascular disease: pathophysiology, clinical consequences, and medical therapy: part I. Circulation 2003; 108(12): 1527-1532.

37. Migliacci R, Nasorri R, Ricciarini P, et al. Ankle-brachial index measured by palpation for the diagnosis of peripheral arterial disease. Fam Pract 2008; 25(4): 228-232.

38. Santosa A, Listiono D. Prediksi Score Ankle Brachial Index (ABI) Ditinjau dari Tanda dan Gejala Peripheral Arterial Disease (PAD). Jurnal IImiah IImu-ilmu Kesehatan 2017; 15(2): 118-128 (in Indonesian).

Tables: 2

Figures: 0

References: 38

Received: 05.02.2018

Reviewed: 09.05.2018

Accepted: 14.05.2018

Address for correspondence:

Rina Amelia, MD, PhD

Department of Community Medicine and Public Health

Faculty of Medicine

Universitas Sumatera Utara

Medan

Indonesia

Tel.: +628116180352

E-mail:drrinaamelia@gmail.com,rina2@usu.ac.id 